\title{
Constructing the Neighbourly "Other": Trade Relations and Mutual Perceptions across the Vietnam-China Border
}

\author{
Kirsten W. Endres
}

The normalization of post-war relations in the late 1980s has transformed the Vietnam-China border from a line of demarcation between two hostile neighbours into a zone of profitable economic opportunities. At the Lào Cai central market, Vietnamese small-scale traders and Chinese citizens interact with one another on a daily basis. Their narratives reveal that processes of constructing self-identity and otherness at the Vietnam-China border are ambiguous and multivocal. They attest to historically rooted stereotypes linked to China's claim of civilizational and economic superiority as much as they are conditioned by face-to-face commercial transactions that challenge essentialized assumptions about the cross-border Other.

Keywords: Vietnam-China border, Lào Cai, Hekou, cross-border trade, othering, tourism, markets.

"Without the border we couldn't make a living; there would be no tourists, and no special things to buy. Our houses on either side would be equipped with the same items. So to whom would we sell?" For "Mr Mạnh" and many of his fellow traders at Lào Cai's central market, the border between Vietnam and China is a vital economic resource upon which they draw to sustain their livelihoods. In common with cross-border traders in many parts of the world, they take advantage of arbitrage opportunities by exploiting "differences in prices and exchange rates over time and space via circulation activities" (Williams and Baláž 2002, p. 323). 
More often than not, their economic transactions fall into the realm of the "subversive economy" in that they challenge state attempts "to regulate the movement of people and flow of commodities" (Donnan and Wilson 1999, p. 88), for example by evading (or negotiating) custom duties or by smuggling goods whose importation the state prohibits (Endres 2014). Although the border regime between the two countries imposes certain constraints on cross-border trade, Mr Mạnh considered the existence of the border a necessary precondition for securing a living in the region. "If Southeast Asia would open its borders like Europe, we would have no way of earning our food [làm ăn]", he argued. ${ }^{2}$ For Vietnamese small-scale traders like Mr Mạnh, as well as for his Chinese trading partners, the border between their two countries thus constitutes a zone of ultimately uncertain, oftentimes risky, but potentially highly profitable economic opportunities. These opportunities require people to meet and interact with the neighbourly, yet in many ways unfamiliar, "Other" against and through which borderland identities and alterities are constructed and articulated (Brambilla 2009, p. 584).

Extending for approximately 1,300 kilometres (Amer 2002, p. 1), the land border between Vietnam and China connects the northern Vietnamese provinces of Điện Biên, Lai Châu, Lào Cai, Hà Giang, Cao Bằng, Lạng Sơn and Quảng Ninh with Yunnan province and the Guangxi Zhuang autonomous region in southern China. Its degree of permeability varies widely from one location to another, depending, for example, on the physical and geographical characteristics of the landscape and/or the ethnic group affiliation of the population, which often transcends the national border. Whereas the northern Vietnamese highlands have long been integrated into the structures of the nation-state, many borderland residents in fact "have continued to avoid the intensity of the state's gaze" (Turner 2010, p. 287) and "negotiate the borderline in the way that they best see fit, be it overtly or covertly, to meet and trade" (Turner 2010 , p. 284). The overall themes that relate to the dynamics of cross-border trade between Vietnam and China, such as transnational mobility, seasonal or permanent migration, local and international 
tourism, thus play out differently in different places. Likewise, the marketplaces of different borderland communities are characterized by a high degree of diversity in spatio-temporal features, ethnic composition of vendors and patrons, product specialization (local produce, China-made goods), clientele (local/translocal) and in seasonality. Whereas periodic upland markets and ethnic minority trade relations have been extensively studied (for example, Bonnin and Turner 2014; Tugault-Lafleur and Turner 2009; Turner and Michaud 2008; Turner 2010; Schoenberger and Turner 2008; Turner, Bonnin and Michaud 2015), anthropologists have not yet accorded much attention to Vietnamese and Chinese ethnic majority crossborder traders and their discursive strategies of self-representation and "othering".

A central concept in post-colonial theory, the notion of the Other is "rooted in the Freudian and post-Freudian analysis of the formation of subjectivity" (Ashcroft et al. 1998, p. 169). It has been used in Subaltern Studies to conceptualize colonial subjects as constituted by the discourse of domination. Spivak (1985) has termed this discursive process of constructing an alien, subjugated and inferior Other "othering". In a more general sense, othering has come to denote processes of representing individuals or social groups in ways that render them "not only different or distant but also alien or deviant, relative to the norms and expectations of the speaker's own group" (Coupland 2010, p. 244). Othering thus creates differences and draws boundaries between groups of people, thereby contributing to processes of identity construction. As Connolly aptly points out, "[i]dentity requires difference in order to be, and it converts difference into otherness in order to secure its own self-certainty" (Connolly 2002, p. 64). Othering is therefore a dialectical process by which the Self is constituted through its distinction from the Other (Ashcroft et al. 1998, p. 171). Such processes of constructing otherness (or alterity) typically take place in the context of power differentials, as "power is always inscribed in the relation an exclusive identity bears to the differences it constitutes" (Connolly 2002, p. 66). 
These briefly sketched theoretical considerations form the backdrop against which this article details some of the ways in which smallscale traders at the Vietnam-China border perceive and construct Self and Other in the context of their everyday economic interactions. Drawing on ethnographic data collected during six months of fieldwork conducted between 2010 and 2012, followed by shorter visits in 2013 and 2014, I examine the ways in which Vietnamese traders belonging to the Kinh ethnic majority and their Han Chinese suppliers and patrons in the twin border cities of Lào Cai, in Lào Cai Province, and Hekou, in Yunnan Province, discursively frame their commercial encounters and exchanges with the cross-border Other. Informal conversations and interviews with male and female Vietnamese vendors at my main field site, the Lào Cai central market, as well as observation of these vendors' daily interactions with Chinese suppliers and customers allowed me to gain insights into the traders' perceptions and attitudes. Occasionally, I also took day trips to Hekou on a Chinese multiple-entry visa to observe activities on the other side of the border and meet with the mobile Chinese cross-border traders with whom I had become acquainted at the market on the Vietnamese side, as well as with some of the Chinese wholesalers and shop owners from whom Vietnamese traderintermediaries like Mr Mạnh obtained their wares.

Recent studies on borderlands and cross-border movements of people, goods, information - have stressed that rather than constituting more or less fixed markers of state territoriality that contain distinct societies, borders are continuously maintained and reproduced through various social actors, relationships, discourses and practices (van Schendel 2005, p. 46). Yet borders are also productive spaces in which identities and meanings are constructed through perceptions and discourses of difference that position the cross-border Other in relation to the Self (Hall 1996, p. 4). In order to understand these everyday processes of "bordering, ordering and othering" (van Houtum and van Naerssen 2002, p. 134), we also need to pay attention to the broader historical, political and ideological contexts that have shaped them. 
In their long common history, bilateral relations between Vietnam and China have ranged from uneasy accommodation to outright hostility. William Duiker describes the historical relationship between China and Vietnam as follows:

Chinese attitudes toward Vietnam combined paternalism and benevolence with a healthy dose of arrogance and cultural condescension stemming from the conviction that it was China that had lifted the Vietnamese from their previous state of barbarism. As for the Vietnamese, their attitude toward China was a unique blend of respect and truculence, combining a pragmatic acceptance of Chinese power and influence with a dogged defense of Vietnamese independence and distinctiveness. (Duiker 1986, p. 6)

For almost a millennium, Vietnam remained a dependency of China and subsequently became sinicized to a considerable extent (Woodside 1971, Pelley 1998). Recent nationalistic attempts at "constructing a coherent Vietnamese past" (Chan 2009a, p. 235) therefore not only glorify the "tradition of resistance to foreign aggression" (Pelley 1995, p. 234) as an essential part of Vietnam's national identity, but also emphasize its cultural independence and distinctiveness from China.

During the First Indochina War (1946-54), China supported Hồ Chí Minh's national liberation effort, and it provided military and economic aid to the Democratic Republic of Vietnam until the end of the Second Indochina War in 1975 (Womack 2010b, pp. 512-13). By that time, however, relations between China and Vietnam had already soured as a result of the Sino-Soviet conflict (Khoo 2011, p. 2). The Vietnamese invasion of Cambodia in 1978 and the contemporaneous massive exodus of ethnic Chinese - locally referred to with the ethnonym "Hoa" - from Vietnam, triggered by a complex interplay of policies, tensions and rumours (Porter 1980, pp. 56-57), further deepened the rift between the two nations. This rift culminated in Chinese forces' 1979 incursion into Vietnam's northern border region (Chen 1987; Zhang Xiaoming 2005).

With the normalization of post-war relations in the late $1980 \mathrm{~s}$, the border gradually transformed from a line of demarcation between 
two hostile neighbours into a vital economic resource and thriving nexus of social and cultural interaction. Although recent disputes involving territorial claims over the Spratly and Paracel islands have again put strain on Vietnam's "asymmetric relationship" (Womack 2010 b, p. 489) with China and stirred up public sentiment in many parts of Vietnam, the "friendship and intimacy rhetoric" (Chan 2013, p. 36) that marked the return to diplomatic normalcy between the two nations has continued to frame economic exchanges in the Sino-Vietnamese borderlands (see Figure 1).

These historical and political contexts and sensitivities, as well as China's recent unprecedented economic success, form part of the background against which this essay ethnographically explores the dynamic and complex processes through which small-scale (ethnic majority) trader identities and alterities are constructed in

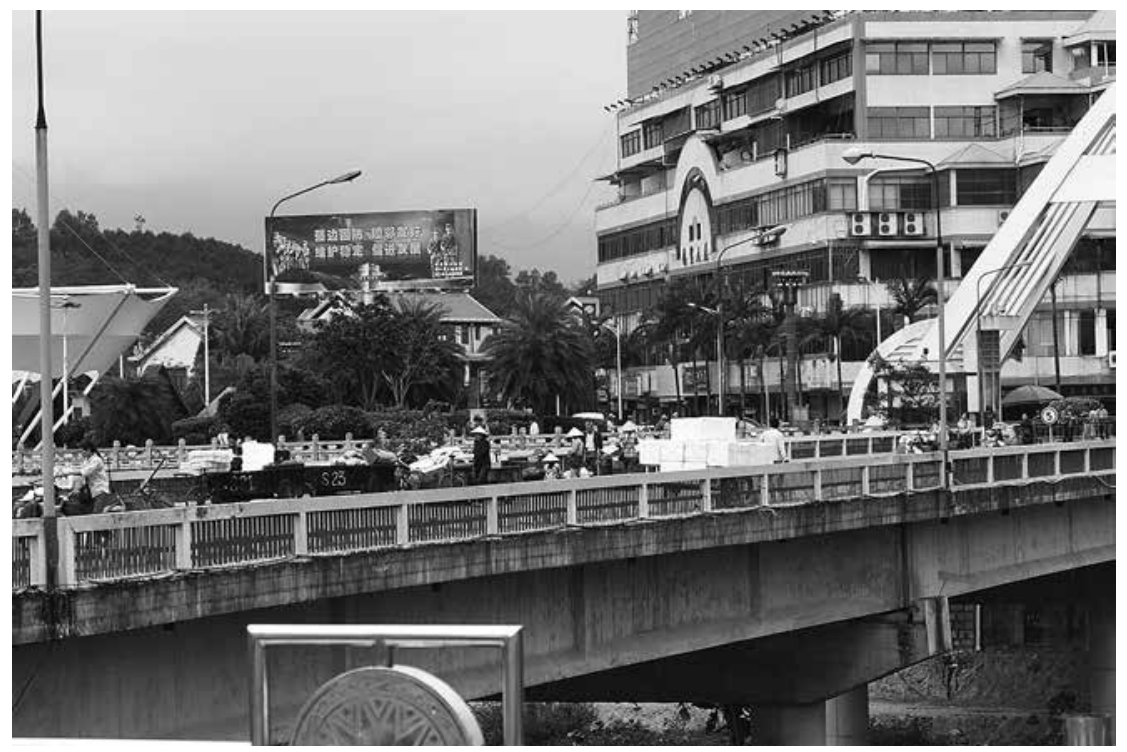

FIGURE 1 View of the bridge connecting Lào Cai, Vietnam, with Hekou in China. The Chinese billboard reads "Strengthen the Border, Solidify Defence, Safeguard Security, Good Neighbourly Relations and Friendship, Advance Development". Photo by the author (April 2013). 
the Vietnam-China borderlands. Unfolding at the intersection of past legacies, socio-political discourses and the localized, everyday experience of and interaction with the neighbourly Other, historically rooted prejudices and political agendas that shape public sentiment mould these identities and alterities as much as economic opportunity, individual self-interest and face-to-face commercial transactions with suppliers and customers from the other side of the border condition them.

\section{Legacies of the Past in Lào Cai City}

Lào Cai City, the capital of the eponymous province, stretches out to the south from the junction of the Red River and Nậm Thi River and borders the Chinese town of Hekou, Yunnan Province. Before Lào Cai (Laokay) came under French colonial rule in 1889, the settlement had become a major hub of the Yunnan opium trade and apparently attracted a significant population of merchants from the provinces of southern China (Davis 2008, p. 62). Towards the end of the 1860s, Lào Cai became a stronghold of the Black Flags, a group of armed bandits under commander Liu Yongfu that enjoyed the backing of the Vietnamese Nguyễn court (Davis 2011, p. 23). When Jean Depuis, a French trader and adventurer, travelled the Red River from Yunnan into Vietnam in 1871, he found Laokay "a wretched assembly of huts which even in its palmy days could never have been prepossessing and now bore a look of the most abject desolation" (McAleavi 1968, p. 95).

French colonial rule gradually transformed Lào Cai into a military and customs post. Between 1901 and 1907, the railway connecting Haiphong, Hanoi and Kunming was built, with Lào Cai as the last station on Vietnamese territory. The Hồ Kiều Bridge across Nậm Thi River, first constructed in 1889, now serves as one of the three international border crossing points between Vietnam and China. ${ }^{3}$ After French colonial rule in Vietnam ended in 1954, Lào Cai continued to be an important border post. Private trade, however, was severely discouraged under the centrally planned economy, 
and cross-border economic activity between Lào Cai and Hekou dwindled to small-scale barter transactions between local residents (d'Hooghe 1994, p. 312). At the time of Vietnam's New Economic Zone programme, launched in the early 1960s, an influx of lowland Kinh settlers, who subsequently came to outnumber the highland minority groups in the province's urban areas, arrived in Lào Cai.

Lào Cai's turbulent past has left few visible traces. During the brief but violent border war of 1979, Lào Cai was razed to the ground. According to Womack (2000, pp. 984-85), “[w]ar with China was serious business for all of Vietnam, but for border towns such as Lang Son and Lao Cai it meant not only devastation, but devastation with no immediate incentive for recovery as long as relations with China remained hostile". Almost all of Lào Cai's residents fled (chay tàu) and either returned to the lowlands or resettled in Yên Bái town, which lay away from the border to the southeast and had become the new provincial administrative centre after the 1976 merger of three northern upland provinces into a single unit named Hoàng Liên Sơn province (Lào Cai 100 tuổi, pp. 31-32). On the Chinese side, many inhabitants of Hekou likewise fled to areas further from the border (Zhang Juan 2011, p. 20). The official border crossing was shut down, and Lào Cai remained largely abandoned for the decade to follow.

Following the normalization of Sino-Vietnamese relations in the late 1980s and early 1990s, Lào Cai province was re-established in 1991 and began to reconstruct its provincial capital. ${ }^{4}$ Border trade gradually resumed after Vietnam issued directive 118 on border trade between China and Vietnam in 1988, and the Lào Cai-Hekou border gate opened as an international border crossing in May 1993 (Lào Cai 100 tuổi, p. 32). On either side of the border, the emerging border economic zones drew internal migrants (back) in anticipation of new - or better - entrepreneurial or livelihood opportunities (Womack 1994; Gu and Womack 2000; Zhang Juan 2011). Smallscale cross-border trade soon flourished and became subject to changing forms of state regulation. Along with new cross-border trading relationships, these developments brought the construction 
and shaping of new images and perceptions of the cross-border Other against the background of historically rooted national stereotypes, current economic conditions and the experience of personal encounters in economic transactions.

\section{Discourses of Superiority and Inferiority}

With a total of over 700 registered vendors at the time of my sixmonth-long research trip in 2010-12, the Lào Cai market was the largest state-owned permanent market in the province. The abundance of its merchandise attracted a wide variety of customers, including residents of the town, members of minority ethnic groups and both domestic and foreign tourists. As is typical in Vietnamese markets along the Chinese border, most of the goods on display came from China. They included household electronics ranging from hair dryers to flat-screen television sets, both genuine and counterfeit mobile phones, garments and textiles, shoes, children's toys, bags and suitcases, decorative feng shui objects, and a vast array of small items such as flashlights, hand-held massagers, keyrings and hairpins.

"Our government has launched the campaign 'Vietnamese people use Vietnamese goods', but everyone, from worker to leader, prefers to use Chinese goods because they are cheaper and better designed!"5 This statement from one of the vendors in the Lào Cai market succinctly captures the ambivalent attitude that prevailed among its stallholders towards China's economic dominance in the region. The sheer volume of mass-produced, low-price goods, the abundance of designs and models and the speed at which Chinese products had flooded the world market were a matter of much admiration, albeit admiration mixed with reservations about quality and durability. Although Vietnamese vendors were aware that China produces many high-quality products, they usually perceived the goods sold at the Lào Cai market as sub-standard items (hàng đểu) that fell apart or broke down after only a short period of use. "Mr Thanh", a stallholder selling Vietnamese wooden handicrafts, saw it this way: 
The Chinese are very clever. They like wooden handicrafts as souvenirs, because in China they don't have as many kinds of precious woods as we do. Coming to Vietnam, the Chinese like buying quality items, whereas what they sell to us is just junk, such as these feng shui objects made of plastic granulate that only last a few years and harm the environment and our health. ${ }^{6}$

Mr Thanh's critical considerations characterize the economic power asymmetries between Vietnam and China in terms describing a neocolonial regime that capitalizes on the extraction of valuable resources from its less-developed neighbours while dumping inferior products in their markets. Some critics have described these products as "trash thrown into the neighbour's garden". ${ }^{7}$ On the positive side, Vietnamese traders acknowledged that even good quality Chinese products, particularly true for electronic goods, were still much cheaper than locally produced wares. Some noted that cheap, low-quality goods in fact served the needs of the poor, who would otherwise not be able to afford the comforts brought by modern technology and scientific progress. In a sense, then, Vietnamese traders also perceived China as contributing to the well-being of economically disadvantaged groups. ${ }^{8}$

China's economic prowess also provided a backdrop against which notions of superiority and inferiority were reflected, reinforced and challenged. "The Chinese leadership thinks little of Vietnam", one male Vietnamese vendor complained, "and so do the Chinese people. They say that even in one hundred years Vietnam will not yet have caught up with them." For "Mr Shengli", a mobile Chinese trader who supplied Lào Cai market vendors with assorted souvenir items (see Figure 2), the reasons for Vietnam's poor economic performance were obvious:

The Vietnamese evade taxes and smuggle a lot, and this is why the state is poor and cannot invest sufficiently in infrastructural development. The Chinese state, in contrast, invests a lot in infrastructure such as road construction; it also imposes many more taxes, such as property tax, and enforces stricter tax laws, whereas in Vietnam anything goes! ${ }^{10}$ 


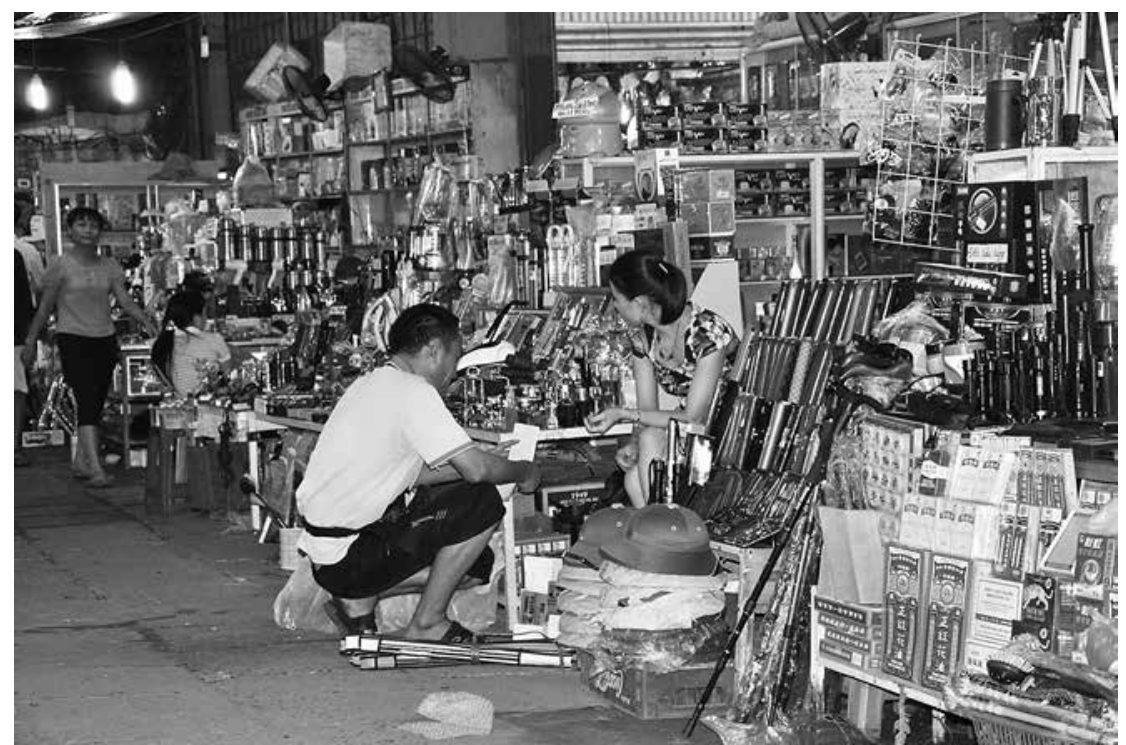

FIGURE 2 A mobile Chinese trader delivers goods to one of the souvenir stalls at Lào Cai market. Orders and outstanding debts are written down in a notebook. Photo by the author (September 2012).

Despite their respect for China's infrastructural progress and alleged achievements in fighting corruption, Vietnamese traders nevertheless felt that the grass was not always greener on the other side. Some of those who frequently commuted across the border even perceived the town of Hekou, with its modern high-rise apartment buildings and treeless streets, as dusty and gloomy. Others remarked that China's rapid economic development was only concentrated on certain regions and had not yet reached the country's remote hinterlands, inhabited by ethnic minority populations, whereas Vietnam had (allegedly) made considerable progress in this regard. Furthermore, they noted the growing divide between rich and poor and the difficulties of finding employment - problems that of course also concern Vietnam — as the unavoidable flip side of increased exposure to market forces. ${ }^{11}$

Their frequent encounters with tourists from all walks of life largely shaped perceptions of the Chinese Other among vendors in 
the souvenir section of the Lào Cai market. As Lào Cai City itself did not have much to offer in terms of major tourist attractions, most tourists only spent a few hours in town before heading to their actual destination in Vietnam. Vietnamese and non-Chinese international tourists were typically on their way to or from the former French hill station of Sapa, which has been the most important tourist hub in the province since the early 1990s (Michaud and Turner 2000, p. 91). Chinese tourists, in contrast, were less interested in ethnicminority tourism and had either booked a one-day Lào Cai city tour, sometimes as part of their organized travels in Yunnan province, or a five-day package that also included Hanoi and Halong Bay (Chan 2009b, pp. 208-9). Chinese companies arranged and sponsored many of these tours as a treat for their employees, for whom a trip to Vietnam would perhaps otherwise not have been affordable (Chan 2013, p. 75). These - often rather rustic - lower-income tourists usually came to the Lào Cai market in large groups led by a tour guide, and were easily recognizable in their identical baseball caps. A common selling strategy among vendors was to offer free samples - a cigarette, a cup of instant coffee - to get the Chinese tourist to sit down at the stall. Some vendors - especially those who could speak conversational Chinese - had established friendly relations with tour guides, who consequently led groups to their stalls on a regular basis. Whereas small groups of wealthier Chinese, most often businessmen, easily succumbed to the charms of the women vendors and often ended up buying many items just for the sake of it, many of the group tourists simply seized the opportunity to enjoy free coffee and cigarettes without buying anything. "Sometimes they just sit around, smoke and drink for free, and then they just leave without even saying thank you", one of the vendors complained. "However, I still have to be nice to them; otherwise the tour guide might perhaps not come back to my stall next time!" 12

In the eyes of the souvenir vendors, this latter type of Chinese tourist ranked the lowest. "These guys usually come from rural areas; they are rather poor, poorly-mannered and uneducated", one vendor reasoned. "They don't know much about the world and have no idea about what they should buy. In fact they do not even care 
whether the goods have been produced in China or in Vietnam."13 The vendors did not see the tour guides - to whom they typically paid a sales commission - in any better light: "They're not welleducated either, earn very little and get no tips from the tourists, which is why they depend on the kickbacks we pay them." 14

Vietnamese female market vendors, often viewed as representing backward and uneducated elements in Vietnamese society, generally place a high value on their children's education (Leshkowich 2011, 2014). Their encounters with less-educated clients, most often of rural origin, not only made them feel morally superior as caring parents, but also prompted sweeping generalizations about their Chinese customers' attitudes towards education. "In rural China they don't value learning much", one of the souvenir vendors argued:

Like that girl over there [pointing to one of the Chinese tour guides]; she left school after the seventh grade to work as a tourist guide. Her parents felt fine with it; they don't give much importance to education. As Vietnamese parents, we would have been in uproar and beat the kid until it went back to school! ${ }^{15}$

\section{Constructions of the Gendered Other}

Whereas comments like those quoted above questioned the civilizational superiority of the Chinese vis-à-vis the Vietnamese - once designated as "Southern Barbarians" by the Han emperors (see Pelley 2002, pp. 148-49) - discourses on gender relations pointed to the opposite conclusion. With one exception, all of the vendors in the souvenir section of the Lào Cai market were women, with an average age between thirty and forty-five. Family issues and gender disparities were particularly hot topics of debate during the idle hours at the market when few customers were around. In informal conversations, the female vendors often praised Chinese men for their respectful conduct towards women, especially in comparison to the vendors' male compatriots. "Ms Phường", a headstrong souvenir vendor in her late forties, explained: 
In China, gender relations are more egalitarian, and Chinese men treat women in a much more respectful manner. Vietnamese men are behind the times (lac hạu) and narrow minded. Like frogs sitting at the bottom of a well, they think that the sky is as small as the lid of a cooking pot (ếch ngồi đáy giếng coi trời bằng vung)! ${ }^{16}$

As an unmarried and childless woman who has long since passed what is considered as marriageable age in Vietnamese society, Ms Phường suffered the lack of social recognition that is associated with the stigma of having been "left on the shelf" (ế chồng) (Bélanger 2004). Over the years, she had established friendly relationships with Chinese people from many walks of life, and she visited Hekou almost every evening to participate in the activities of one of the sidewalk dancing groups there. Among her male and female Chinese friends, she felt at ease and was treated with dignity. From her own experiences and observations she thus concluded that unmarried women like her were perhaps less stigmatized in Chinese society. The evidence does not, however, support her inference. In China today, just as in Vietnam, it is still widely assumed that "remaining single is abnormal and represents failure as a woman" (Zhang and Sun 2014, p. 125; see also Fincher 2014).

Women who had family histories of domestic violence or drugaddicted husbands that had led to divorce or separation also held the view that Chinese men were more respectful and caring than their Vietnamese counterparts. "Mrs Hiền", an attractive thirty-nineyear-old divorcee, expressed her opinion as follows:

Honestly, I'm fed up with Vietnamese men. They hang out late and then in cowardly fashion beat up their wives and children. But Chinese husbands, be they employees or big bosses, are henpecked; it is normal for them to return home straight after work and do the cooking and laundering. ${ }^{17}$

Chinese men, in contrast, are likely to feel attracted to the female Other because she embodies virtues that, allegedly, were lost in 
the process of Chinese female emancipation. As Caroline Grillot (2012, p. 135) notes, "Vietnamese women recall for Chinese men a nostalgic picture of what Chinese women used to embody", that is, an image that supposedly represents the Confucian ideal of a virtuous, submissive and dutiful wife. Her finding resonates well with the ways in which matchmaking agencies that promote Vietnamese women as potential spouses for East Asian men often depict them (Belanger and Wang 2012, p. 296). Marrying a woman from an economically inferior country may also allow men to feel superior, particularly if they belong to a disadvantaged social class.

In her work on Sino-Vietnamese couples in Hekou, Grillot (2014) has shown that the number of cross-border marriages between Vietnamese women and Chinese men has been increasing with the opening up of business opportunities and the subsequent influx of migrants to the region. These marriages are often grounded in pragmatic interests and desires related to building cross-border business networks and ensuring better material lives. On the one hand, as Grillot argues with reference to the Chinese husbands in these marriages, such pragmatism "is not considered to be a negative factor, but a personal and patriotic way of penetrating further into a land where local guidance is necessary in order to establish long-term collaboration despite obstacles" (Grillot 2014, p. 362). On the other hand, however, people in Hekou often perceive mixed couples with suspicion and ambivalence. Grillot aptly reads these sentiments as "a form of intimate resistance to collaborating with a former enemy and a still uncertain economic partner" (Grillot 2014, p. 373).

The development of transborder trade and tourism in the Vietnam-China borderland has in many ways also contributed to the "sexualization and sensualization of the border" (Chan 2009a, p. 221). For male Chinese pleasure-seekers, the large number of young Vietnamese women working in the border area's burgeoning sex service sector "embody the fantasy of the exotic sexual encounter on the border" (Grillot 2012, p. 130), and a visit to a brothel or massage parlour is often high on their list of tourist attractions in Vietnam (Chan 2009b, p. 210). According to Zhang Juan (2012), 
many of the Vietnamese girls in the sex market actually see their work not as a means of mere survival, but as a way of effectively accumulating enough capital to pursue an alternative future. Their straightforward and sometimes even aggressive style of approaching potential clients often leads Chinese men to perceive them "as capable and scheming gold diggers rather than as innocent country girls tricked into sexual exploitation" (Zhang Juan 2012, p. 101; see also Zhou and Duong 2011).

The sometimes rather aggressive and straightforward marketing strategies of Vietnamese women vendors may actually reinforce such perceptions, albeit in a different, non-sexualized context. An episode from my fieldwork illustrates this point. One day in February 2011, a small group of rather well-dressed Chinese visitors approached the market stall operated by "Mrs Mai" with clear ideas about the kind of cigarettes that they wanted to buy. Mrs Mai, however, did not stock this variety and tried to convince them to buy another one. Then, when her stall helper dashed away to borrow a few cartons of the desired brand of cigarettes from another stall, the vendor in the stall opposite Mrs Mai's quickly grasped the situation, grabbed a carton of the requested brand and sealed the deal before Mrs Mai's helper returned to the scene. After the Chinese customers had paid for their purchase, Mrs Mai started urging them to buy an additional two cartons of cigarettes from her. When the men declined the offer and walked off, she ran after them, loudly arguing that they had wanted to buy the cigarettes from her in the first place, and that now that she could supply them they were obliged to buy. Mrs Mai's stall helper came running with a plastic bag, put the cigarette cartons inside, and pushed them on the Chinese customers, who eventually gave in - whether out of desperation, fear or for the sake of peace, I am unable to tell. They handed Mrs Mai two hundred yuan, equivalent to six hundred thousand dồng, or approximately USD28 at that time. Mrs Mai clutched the money in both hands, politely thanked the Chinese, and ran off bending over with laughter because of the large profit she had extracted. ${ }^{18}$ 
While I was unable to find out how Chinese customers perceived situations like this one, I feel safe in assuming that such encounters rather project an image of cantankerous, money-grabbing womenfolk than feed into notions of submissiveness and obedience.

The examples cited above make clear that processes of constructing self-identity and otherness at the Vietnam-China border are inherently ambiguous and multivocal. Whereas some of the traders' representations of Self and Other attested to historical prejudices linked to China's claim of civilizational and economic superiority, different images emerged from personal encounters in a variety of contexts. These images challenged essentialized assumptions about the cross-border Other. Some of them served as a negative foil for the construction of a positive self-identity, while still others embodied a critique directed against the social conditions and societal attitudes that were responsible for negative experiences in people's daily lives. This latter use of images of the Other appeared to hold particularly true for single or divorced Vietnamese women traders who felt constrained by the prevailing gender ideologies and inequalities in Vietnamese society. Most importantly, however, crossborder trade relations also involved dealing with cultural differences in entrepreneurial ethics and business practices. The next section of the article focuses on the ways in which such differences have an impact on Vietnamese and Chinese traders' mutual perceptions and representations.

\section{Trade and Trust across the Border}

Vendors in the Lào Cai market make use of different import options in order to obtain their Chinese-produced wares. They can make the trip to Hekou themselves and pick from various wholesalers who own shops in the town centre (see Figure 3), an option that in fact only very few market stallholders choose. Alternatively, they can use the services of trader-intermediaries and goods transporters (ngườ môi, người giao hàng) and pay a per-piece fee for delivery. Another option 


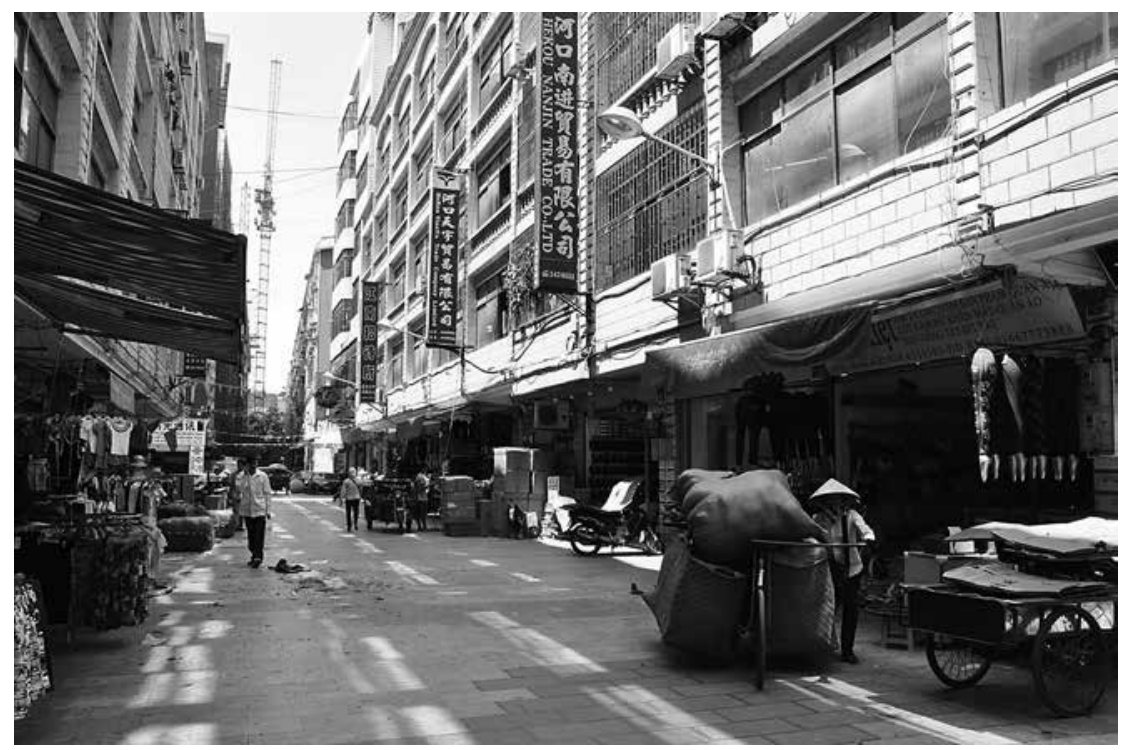

FIGURE 3 One of Hekou's main shopping streets catering to Vietnamese retailers. Cargo bicycles were a popular means of transporting goods across the border until they were banned in January 2014. Photo by the author (September 2012).

is to buy from mobile Chinese traders like "Mr Shengli" who cross the border on a regular basis with small amounts of merchandise. Product specialization (presumably) regulated competition among importers of the latter kind: each mobile trader only sold a range of certain goods over which he or she then enjoyed price-setting power. ${ }^{19}$

Generally speaking, Vietnamese vendors tended to describe the attitude of Chinese traders towards building positive trading relationships as primarily profit-oriented (thân vì có lợi). Moreover, Vietnamese traders often perceived their Chinese business partners as not stressing tìn cảm (sentiment) as much as the Vietnamese did. According to Malarney (2003, p. 190),

[h]aving sentiment with another implies ... a feeling of warmth and affect, a sense of unity that transcends any status differences and an abiding conscientiousness in which one will willingly make personal sacrifices to assist the other. 
Constructing relationships based on tình cảm is thus an essential part of being a moral person. In the economic sphere of the marketplace, tình cảm was expressed through mutual support and cooperation in handling daily affairs, as well as through participation in important events in the lives of fellow traders and their families, such as weddings and funerals (see also Leshkowich 2014, pp. 114-18; Endres 2015).

Informants considered this highly valued and constitutive element of Vietnamese social relationships lacking not only in Chinese business relations but also in Chinese society as a whole. "They [the Chinese] only socialize with each other (choi vori nhau) if they see an advantage (lợi nhuận) for themselves", said a male vendor who usually bought his merchandise in Hekou. ${ }^{20}$ One of the female souvenir vendors supported this claim in more accusatory language:

Those Chinese are pretty clever. They are friendly with you if they sense a profit opportunity; if not, they turn their back on you instantly. If you don't trade with them for a while, their attitude gets as stale as snail water, or they turn really cold if you don't bring them profit. ${ }^{21}$

This perception of the Chinese Other as primarily motivated by mercenary self-interest is not uncommon in Southeast Asia and resonates with the anti-Semitic stereotype of the greedy Jew (see Chirot and Reid 1997). Vietnamese traders, in turn, are often perceived by their Chinese suppliers as untrustworthy, especially with regard to their debt repayment practices.

According to Marshal Sahlins (1972, p. 196, cited in Peebles 2010 , p. 232), "the span of social distance between those who exchange conditions the mode of exchange". Within these varying modes of exchange, "enemies suffer theft, strangers tolerate higgling commercialism, and kin and neighbors expect fair and binding credit/ debt relations" (Peebles 2010, p. 232). In common with small-scale traders in other parts of Southeast Asia (Alexander 1987; Geertz 1963; Davis 1973), Vietnamese small-scale traders largely depend on credit from their suppliers; they usually buy goods on a credit 
or instalment basis and make payment at a specified time, or else after the goods have been sold. Vietnamese debt repayment practices, however, apparently pose a huge challenge to the trade ethics of Chinese nationals. According to "Mr Fuhua", a mobile trader who supplied Lào Cai market vendors with cheap perfumes, a Chinese entrepreneur has to adhere strictly to the terms of payment agreed with his suppliers, lest they come to see him as untrustworthy and terminated their trade relations with him. ${ }^{22}$ The biggest difficulty that Mr Fuhua faced in trading with Vietnamese market vendors was to collect the money they owed him. He grumbled,

With a few exceptions, the vendors usually come forward with all sorts of excuses for not paying their debts. It may be the first or the fifteenth of the lunar month [i.e., days dedicated to fulfilling ritual obligations], or it rains, or they've had few customers on that day and could not sell much; so I usually have to return many times in order to collect just a few hundred thousand dồng, which is really annoying.

Mr Shengli experienced the same attitude towards payment obligations among Vietnamese traders. "Some actually have the money, but they still postpone paying for the goods; they just don't care about trust [or trustworthiness] in trading relationships", he complained. ${ }^{23}$ In August 2012, Mr Shengli estimated Lào Cai market vendors' total outstanding debts to him at 700 million đồng (USD33,120). ${ }^{24}$ In order to prevent losses due to fluctuations in the exchange rate, he resorted to charging his clients a slightly higher price for the goods that he delivered to them if they did not pay immediately upon delivery. This practice, however, earned him a good measure of insult and reproach from an outspoken souvenir vendor named "Mrs Hồng": "Jeez, this Shengli guy is so ill-bred (mất dạy), selling dear to us!!!" 25 Whereas Mr Shengli enjoyed popularity among the vendors for his jolly demeanour and bawdy humour despite his approach to pricing, "Mr Longwei", a Chinese supplier of cigarettes and liquor, was widely regarded in the Lào Cai market as "a dirty scumbag in every possible sense" (thằng bẩn theo mọi nghĩa), ${ }^{26}$ for the main 
reason that he always demanded cash up front for his merchandise. According to Mrs Hồng, "[t]hat bugger (thằng) Longwei makes lots of money, but he is such a dirty character; he demands money first thing and wouldn't let us buy on credit!"27

Vendors in the souvenir section of the Lào Cai market depended heavily on seasonal tourism for their incomes and generally sold at very low profit margins. They therefore had to rely on higher sales volumes than, say, vendors of electronic household appliances or items hand carved from precious wood, in order to survive. As their capital resources were limited, small traders like Mrs Hồng often ran short of cash and were unable - or pretended to be unable - to meet their debt obligations. Mobile Chinese traders and middlemen like the three mentioned above in turn depended, to a very large extent, on the vendors of Lào Cai for their business and grudgingly had to put up with their slow payment habits.

In contrast, Vietnamese traders and intermediaries who bought their merchandise from Chinese wholesalers in Hekou had to comply with the payment terms set by their suppliers in order to be regarded as trustworthy trading partners committed to long-term relationships for mutual profit. Chinese merchants who had been able to establish themselves as shop owners in one of Hekou's wholesale and retail streets usually maintained a wide range of trade relations and thus had clear advantages over mobile traders like Mr Shengli, Mr Fuhua and "Mr Liwei", mentioned below, who sold their wares directly to Lào Cai market vendors. In order to assess the creditworthiness of a new customer, Chinese shop owners commonly insisted on a trial period during which they carefully observed the client's behaviour. If the client managed to establish a record of credibility, the shop owner trader gradually raised the amount of credit available to him or her until it reached the limit that the shop owner deemed appropriate in the given circumstances (Barton 1977, pp. 233-36). Mr Mạnh, the Vietnamese intermediary mentioned in the introduction, explained this process as follows:

After one or two years of trading and knowing each other (quen nhau), they would allow me to purchase on credit (mua chịu) 
because I never betrayed my trustworthiness (không làm mất uy tín). Once you have established trust, trading conditions get more favourable (thuận lọi hon); they would let you order larger quantities for example. It is easier to make a living (dễ làm ăn hon) on the basis of a long-term relationship, and you also get to know more people. ${ }^{28}$

Mr Mạnh supplied Lào Cai-based market vendors with electronic goods purchased in Hekou. Together with his sister and two brothers-in-law, he crossed the border several times a day in order to buy, transport and distribute merchandise. Over time, he had established trust with Chinese shop owners and enjoyed favourable discounts and payment/credit terms. One of his regular providers was Mr Liwei, a Hekou shop owner and wholesaler whose family had migrated from Hunan province in the early 1990s. Because of their long-term business relationship, Mr Liwei allowed Mr Mạnh to buy up to a maximum of CNY20,000 (USD3,169) worth of goods at a time on credit. At the time of his next purchase, Mr Mạnh had to settle a portion of his previous debt, in a practice called trả gối. At Mr Liwei's shop, Mr Mạnh was allowed to accumulate a maximum debt of CNY70,000 (USD11,065), to be settled at the end of the year. At the Lào Cai market, Mr Mạnh supplied approximately forty stalls with household electronics and collected at least partial payments for the goods on a daily basis. The maximum credit that he extended to each stallholder was limited to one to two million đồng per month (USD47-95). "Trading this way does not require a large amount of capital," Mr Mạnh said. "My main capital is the trust I have built up with the Chinese traders." 29

Mr Mạnh's long-term relationships of trust with suppliers across the border had shaped his perceptions of Chinese in ways that stood in striking contrast to their depiction as ruthless and calculating in their behaviour, and that rendered difference into sameness. "They live the same kind of business life that we do", he mused. "With regard to sentiment, the language barrier is a little bit of a problem, but once they can speak Vietnamese, we are like brothers and sisters." 30

For the Chinese shop owners in Hekou, however, the situation was more complicated. According to one of the electronics merchants 
in Hekou's busy wholesale and retail streets, Chinese traders had to pay their suppliers within three months' time, if not immediately. "If I don't have the money, I have to borrow from my friends in order to pay for the goods", one of Mr Mạnh's suppliers explained, whereas the Vietnamese would pay some this month and some the next. "They always buy on credit", he said. "In Vietnam, everyone is in debt [ai cũng $\left.n o^{\top}\right]$ ". He estimated that Vietnamese traders owed him a total of 1.5 billion đồng [USD71,256]. Yet this amount, he claimed, was not very large compared to the outstanding debts owed to the Hekou shoe traders, which could amount to as much as ten billion đồng [USD475,041]. In his view, therefore, it was harder for the Chinese to make a decent living than it was for the Vietnamese. ${ }^{31}$

In recent times, small-scale trade across the Vietnam-China border has allegedly become harder for both sides. Not only have Lào Cai market vendors experienced a steady decline in tourist numbers over the past five years, but they also have had to deal with unpredictable customs practices and transport regulations at the border checkpoint. This unpredictability contributed to a decrease in small-scale trade flows. Uncertainties associated with the most recent developments in the dispute between Hanoi and Beijing concerning the South China Sea and fears of a possible escalation in those disputes have only compounded these challenges. While diplomatic tensions between Vietnam and China have been growing, traders like Mr Mạnh and his Chinese suppliers have continued to stay on friendly terms, as they depend on one another for their livelihoods. "Whether we are facing difficult times or easy times, we still do business. It's our relationships that matter", Mr Mạnh said. "Concerning politics, I don't know anything about that. I'm just an ordinary person." ${ }^{32}$

\section{Conclusion}

Borders and boundaries, as Newman and Paasi (1998, p. 194) point out, "not only separate groups and communities from each other but 
also mediate contacts between them". In this article, I have drawn on ethnographic material collected through participant observation and conversations with Vietnamese and Chinese small-scale traders at the Lào Cai-Hekou international border in order to explore some of the ways in which cross-border trade relations shape mutual perceptions and contribute to the construction of Self and Other. My attention primarily focused on small-scale economic exchanges among three types of actors in the local cross-border trade: Vietnamese market vendors and intermediaries, Chinese shop owners and mobile shuttle traders, and Chinese tourists shopping for souvenirs at Lào Cai market. With a few exceptions, the protagonists quoted in this article have moved to the border area from areas of China and Vietnam distant from the international border in order to seize the economic opportunities at hand. Whereas the great "gold rush" to Hekou (Zhang Juan 2011, p. 126) and Lào Cai has clearly subsided and traders on both sides have claimed that business is no longer as profitable as in the 1990s and early 2000s, cross-border trade has remained an important part of the local economy.

The narratives and perspectives that I have recounted demonstrate that borderland identities and alterities must be seen as continuous and dynamic processes that both reflect and transcend boundarymaking practices based on historically rooted prejudices and contemporary political agendas. On the one hand, and this is particularly true for the fleeting transactions between vendors and tourists, economic encounters contribute to the construction of a generalized and stereotypical Other to which traders compare and contrast themselves. On the other hand, the ability and willingness of Vietnamese and Chinese traders to adhere to the business codes and ethics that prevail among their trading partners also condition their attitudes towards one another. Here, the rules of the game were to a great extent determined by the party to a transaction on whose side of the border the deal was sealed. Another factor was the size and volume of the parties' respective businesses. A Chinese shop owner with a large clientele that reached beyond Lào Cai City was certainly in a stronger position to set payment conditions 
than a mobile shuttle trader who relied on clients at one particular Vietnamese market and therefore had to make more concessions to Vietnamese credit/debt practices. Conversely, a Vietnamese goods transporter or middleman or middlewoman had to comply with the payment conditions set by his or her Chinese supplier in order to gain the trust necessary for a long-term trading relationship under more favourable credit terms.

Although Chinese imports into Vietnam clearly continue to dominate bilateral trade relations between the two countries, a high degree of mutual dependency characterizes cross-border economic ties. Small-scale traders on both sides consequently emphasized that it was the very existence of the border that enabled them to make a relatively decent living in this region. Their constructions of Self and Other take shape through a multitude of everyday encounters and economic exchanges in the Vietnam-China borderlands. The border thus emerges as a productive site, in providing not just access to economic opportunity but also a boundary through and across which identities are shaped. As complex, multidimensional processes that involve both short-lived interactions and carefully cultivated relationships with the neighbourly Other, these borderland identities and alterities are continuously in the making. This fluidity is not only part of the border region's overall socio-economic dynamics, but also a phenomenon that contributes to the conception of the Vietnam-China border as a site of potential political volatility and economic uncertainty.

\section{Acknowledgements}

Research for this article was conducted as part of a cooperative agreement between the Max Planck Institute for Social Anthropology, Halle/S., Germany, and the Institute of Anthropology, Vietnam Academy of Social Sciences, Hanoi. Earlier drafts of this paper were presented at the conference on "Vietnam and its Minorities, Vietnam and its Neighbors - are there Historical Lessons for the 21st Century?" (Hamburg, 9-10 June 2012) and during an Institute 
Colloquium at the University of Göttingen (29 January 2013), where it benefitted from comments by Christine Bonnin, Peter Bräunlein, Michael Dickhardt, Jörg Thomas Engelbert, Andrea Lauser, and Li Tana. At the Max Planck Institute for Social Anthropology, I received further valuable suggestions from Minh T.N. Nguyen and Roberta Zavoretti. I am most grateful to the two anonymous reviewers for pushing me towards further engagement with relevant debates, and to Michael Montesano for expert editing of the final manuscript.

Kirsten W. Endres is Head of Research Group in the "Resilience and Transformation in Eurasia" Department, Max Planck Institute for Social Anthropology, Advokatenweg 36, 06114 Halle/Saale, Germany; email: endres@eth.mpg.de.

\section{NOTES}

1. Interview by author, Lào Cai City, 6 September 2012. I am immensely grateful to my assistant Tâm, whose masterly skill in capturing the voices of our interlocutors in her field-notes allowed me to stay as close as possible to the original wording in my translations. Informal talks in Chinese were conducted with the much appreciated help of Thảo and Nghĩa. Throughout this article, I use pseudonyms in order to protect my interlocutors' privacy.

2. Interview by author, Lào Cai City, 6 September 2012 .

3. Vietnam generally classifies border crossings into three categories: international crossings (where, aside from local residents who only need a permit, third-country nationals and non-borderland residents are allowed to cross with passports and visas), national-level crossings (where citizens of both countries may cross with a visa or permit), and so-called supplementary crossings, usually in remote areas (where borderland residents are the only ones who are allowed to traverse the border) (Turner 2010, pp. 281-82).

4. Lào Cai achieved city status (thành phố) in 2005 and currently counts approximately 100,000 inhabitants.

5. Interview by author, Lào Cai, 13 October 2010. The current campaign was launched in 2009 by the Politburo of the Communist Party of Vietnam and aims at promoting patriotism as well as national production (see http://www.tuhaoviet.vn/index.php/home/gioi-thieu-tong-the, accessed 23 December 2014).

6. Interview by author, Lào Cai, 24 December 2010 . 
7. Informal conversation with Hanoi-based intellectual, author's field-notes, December 2011.

8. Author's field-notes, Lào Cai, October 2010-March 2011.

9. Interview by author, Lào Cai, 13 October 2010 .

10. Interview by author, Lào Cai, 19 December 2010 .

11. Author's field-notes, October 2010-March 2011.

12. Interview by author, Lào Cai, 24 December 2010 .

13. Conversation with author, Lào Cai, 23 December 2010.

14. Conversation with author, Lào Cai, 23 December 2010.

15. Conversation with author, Lào Cai, 14 December 2010.

16. Conversation with author, Hekou, 17 September 2012.

17. Conversation with author, Lào Cai, 2 September 2012.

18. Author's field-notes, Lào Cai, 26 December 2010.

19. According to one vendor, the Chinese tradition of trading prescribes that a producer only sells to one specific large wholesaler or agent, from whom (I assume) distribution cascades down to many small retailers and agents like Mr Shengli. The lower-level agents, in turn, then seek to establish their own monopolies by sticking to a set range of goods and operating only in a certain area (conversation with author, Lào Cai, 14 October 2010).

20. Interview by author, Lào Cai, 2 November 2010 .

21. Conversation with author, Lào Cai, 24 December 2010.

22. Interview by author, Hekou, 19 February 2011.

23. Interview by author, Lào Cai, 12 February 2011.

24. Conversation with author, Hekou, 31 August 2012.

25. Author's field-notes, Lào Cai, 11 February 2011.

26. Conversation with author, Lào Cai, 24 December 2010.

27. Conversation with author, Lào Cai, 26 December 2010.

28. Interview by author, Lào Cai, 21 December 2010.

29. Interview by author, Lào Cai, 6 September 2012 .

30. Interview, Lào Cai, April 2013. Many shop-owners in Hekou spoke Vietnamese. At the Lào Cai market, vendors who frequently sold to Chinese tourists usually knew enough Chinese to bargain and make small-talk, and some even mastered the language at a high level.

31. Conversation with author, Hekou, 19 September 2012.

32. Interview, Lào Cai, April 2013.

\section{REFERENCES}

Alexander, Jennifer. Trade, Traders and Trading in Rural Java. Singapore: Oxford University Press, 1987. 
Amer, Ramses. "The Sino-Vietnamese Approach to Managing Boundary Disputes". Maritime Briefing 3, no. 5 (2002).

Ashcroft, Bill, Gareth Griffiths, and Helen Tiffin. Post-Colonial Studies: The Key Concepts. London: Routledge, 1998.

Barton, Clifton Gilbert. "Credit and Commercial Control: Strategies and Methods of Chinese Businessmen in South Vietnam”. Doctoral dissertation, Cornell University, 1977.

Bélanger, Danièle. "Single and Childless Women of Vietnam: Contesting and Negotiating Female Identity?". In Gender Practices in Contemporary Vietnam, edited by Lisa Drummond and Helle Rydstrøm. Singapore: Singapore University Press; Copenhagen: NIAS Press, 2004.

Bélanger, Danièle, and Hong-zen Wang. "Transnationalism from Below: Evidence from Vietnam-Taiwan Cross-Border Marriages". Asian and Pacific Migration Journal 21, no. 3 (2012): 291-316.

Bonnin, C, and S. Turner. "Remaking Markets in the Mountains: Integration, Trader Agency and Resistance in Upland Northern Vietnam". Journal of Peasant Studies 41, no. 3 (2014): 321-42.

Brambilla, Chiara. "Borders: Paradoxical Structures between Essentialization and Creativity". World Futures 65, no. 8 (2009): 582-88.

Chan Yuk Wah. "Language Power: Relational Rhetoric and Historical Taciturnity: A Study of Vietnam-China Relationship". In Connecting and Distancing Southeast Asia and China, edited by Ho Khai Leong. Singapore: Institute of Southeast Asian Studies, 2009a.

- Cultural and Gender Politics in Vietnam-China Tourism. In Tourism in Southeast Asia: Challenges and New Directions, edited by Michael Hitchcock, Victor T. King, and Michael Parnwell. Copenhagen: NIAS Press, $2009 b$.

- Vietnamese-Chinese Relationships at the Borderlands: Trade, Tourism and Cultural Politics. London: Routledge, 2013.

Chen, King C. China's War with Vietnam, 1979. Stanford: Hoover Institution Press, 1987.

Chirot, Daniel, and Anthony Reid, eds. Essential Outsiders: Chinese and Jews in the Modern Transformation of Southeast Asia and Central Europe. Seattle: University of Washington Press, 1997.

Connolly, William E. Identity/Difference: Democratic Negotiations of Political Paradox. Minneapolis: University of Minnesota Press, 2002.

Coupland, Nikolas. “'Other' Representation”. In Society and Language Use, Handbook of Pragmatics Highlights, Vol. 7, edited by Jürgen Jaspers, Jan-Ola Östman, and Jef Verschueren. Amsterdam: Benjamins, 2010.

Davis, Bradley C. States of Banditry: The Nguyen Government, Bandit Rule, 
and the Culture of Power in the Post-Taiping China-Vietnam Borderlands. Doctoral dissertation, University of Washington, 2008.

- "Black Flag Rumors and the Black River Basin: Powerbrokers and the

State in the Tonkin-China Borderlands". Journal of Vietnamese Studies 6, no. 2 (2011): 16-41.

Davis, William G. Social Relations in a Philippine Market: Self-Interest and Subjectivity. Berkeley: University of California Press, 1973.

d'Hooghe, Ingrid. "Regional Economic Integration in Yunnan". In China

Deconstructs: Politics, Trade and Regionalism, edited by David S.G.

Goodman and Gerald Segal. London: Routledge, 1994.

Donnan, Hastings, and Thomas M. Wilson. Borders: Frontiers of Identity, Nation and State. Oxford: Berg, 1999.

Duiker, William J. China and Vietnam: Roots of Conflict. Berkeley: Institute of East Asian Studies, University of California, 1986.

Endres, Kirsten W. "Making Law: Small-Scale Trade and Corrupt Exceptions at the Vietnam-China Border". American Anthropologist 116, no. 3 (2014): 611-25.

- “'Lộc Bestowed by Heaven': Fate, Fortune, and Morality in the Vietnamese Marketplace". Asia Pacific Journal of Anthropology 16, no. 3 (2015): 1-17.

Fincher, Leta Hong. Leftover Women: The Resurgence of Gender Inequality in China. London: Zed Books, 2014.

Geertz, Clifford. Peddlers and Princes: Social Change and Economic Modernization in Two Indonesian Towns. Chicago: University of Chicago Press, 1963.

Grillot, Caroline. "Between Bitterness and Sweetness, When Bodies Say it All: Chinese Perspectives on Vietnamese Women in a Border Space". Journal of Vietnamese Studies 7, no. 1 (2012): 106-48.

. "Private Commitment: Marital Alliance in the Establishment of Business Networks at Hekou-Lào Cai, Twin Sino-Vietnamese Border Cities". In Transnational Dynamics in Southeast Asia: The Greater Mekong Subregion and Malacca Strait Economic Corridors, edited by Nathalie Fau, Sirivanh Khonthapane, and Christian Taillard. Singapore: Institute of Southeast Asian Studies, 2014.

Gu Xiaosong, and Brantley Womack. "Border Cooperation between China and Vietnam in the 1990s". Asian Survey 40 (2000): 1042-58.

Hall, Stuart. "Introduction: Who Needs Identity?". In Questions of Cultural Identity, edited by Stuart Hall and Paul Du Gay. London: Sage, 1996.

Khoo, Nicholas. Collateral Damage: Sino-Soviet Rivalry and the Termination of the Sino-Vietnamese Alliance. New York: Columbia University Press, 2011. 
Lào Cai 100 tuổi: Đặc san Báo Lào Cai [100th Anniversary of Lào Cai. Lào Cai news special on the occasion of the 100th anniversary of the province]. Lào Cai: Báo Lào Cai, 2007.

Leshkowich, Ann Marie. "Making Class and Gender: (Market) Socialist Enframing of Traders in Ho Chi Minh City". American Anthropologist 113, no. 2 (2011): 277-90.

- Essential Trade: Vietnamese Women in a Changing Marketplace. Honolulu: University of Hawai'i Press, 2014.

Malarney, Shaun. "Weddings and Funerals in Contemporary Vietnam". In Vietnam: Journeys of Body, Mind, and Spirit, edited by Nguyen Van Huy and Laurel Kendall. Berkeley: University of California Press, 2003. McAleavi, Henry. Black Flags in Vietnam: The Story of a Chinese Intervention. New York: Macmillan, 1968.

Michaud, Jean, and Sarah Turner. "The Sa Pa Marketplace, Lao Cai Province, Vietnam". Asia Pacific Viewpoint 41, no. 1 (2000): 85-100.

Newman, David, and Anssi Paasi. "Fences and Neighbours in the Postmodern World: Boundary Narratives in Political Geography”. Progress in Human Geography 22 (1998): 186-207.

Peebles, Gustav. "The Anthropology of Credit and Debt". Annual Review of Anthropology 39 (2010): 225-40.

Pelley, Patricia. "The History of Resistance and the Resistance to History in Postcolonial Constructions of the Past". In Essays into Vietnamese Pasts, edited by K.W. Taylor and John K. Whitmore. Ithaca, New York: Cornell University Press, $1995 b$.

. " "Barbarians' and 'Younger Brothers"”. Journal of Southeast Asian Studies 29, no. 2 (1998): 374-91.

- Postcolonial Vietnam: New Histories of the National Past. Durham, North Carolina: Duke University Press, 2002.

Porter, Gareth. "Vietnam's Ethnic Chinese and the Sino-Vietnamese Conflict". Bulletin of Concerned Asian Scholars 12, no. 4 (1980): 55-60.

Sahlins, Marshall D. Stone Age Economics. Chicago: Aldine, 1972.

Schoenberger, Laura, and Sarah Turner. "Negotiating Remote Borderland Access: Small-Scale Trade on the Vietnam-China Border". Development and Change 39, no. 4 (2008): 667-96.

Spivak, Gayatri C. "The Rani of Sirmur: An Essay in Reading the Archives". History and Theory 24, no. 3 (1985): 247-72.

Tugault-Lafleur, Claire, and Sarah Turner. "The Price of Spice: Ethnic Minority Livelihoods and Cardamom Commodity Chains in Upland Northern Vietnam". Singapore Journal of Tropical Geography 30 (2009): 388-403.

Turner, Sarah. "Borderlands and Border Narratives: A Longitudinal Study of 
Challenges and Opportunities for Local Traders Shaped by the SinoVietnamese Border". Journal of Global History 5, no. 2 (2010): 265-87. Turner, Sarah, Christine Bonnin, and Jean Michaud. Frontier Livelihoods: Hmong in the Sino-Vietnamese Borderlands. Seattle: University of Washington Press, 2015.

Turner, Sarah, and Jean Michaud. "Imaginative and Adaptive Economic Strategies for Hmong Livelihoods in Lào Cai Province, Northern Vietnam". Journal of Vietnamese Studies 3, no. 3 (2008): 158-90.

van Houtum, Henk, and Ton van Naerssen. "Bordering, Ordering, and Othering". Tijdschrift voor Economische en Sociale Geografie 93, no. 2 (2002): 125-36.

van Schendel, Willem. "Spaces of Engagement: How Borderlands, Illicit Flows, and Territorial States Interlock". In Illicit Flows and Criminal Things, States, Borders, and the Other Side of Globalisation, edited by Willem van Schendel and Itty Abraham. Bloomington: Indiana University Press, 2005.

Vann, Elizabeth F. "Production Matters: Consumerism and Global Capitalism in Vietnam". Research in Economic Anthropology 22 (2003): 225-57.

Williams, Allan M., and Vladimir Baláž. "International Petty Trading: Changing Practices in Trans-Carpathian Ukraine". International Journal of Urban and Regional Research 26, no. 2 (2002): 323-42.

Womack, Brantly. "Sino-Vietnamese Border Trade: The Edge of Normalization". Asian Survey 33, no. 6 (1994): 495-512.

. "International Relationships at the Border of China and Vietnam: An Introduction". Asian Survey 40, no. 6 (2000): 981-86.

- "China and Vietnam: Managing an Asymmetric Relationship in an Era of Economic Uncertainty". Asian Politics \& Policy 2, no. 4 (2010a): 583-600.

- China among Unequals: Asymmetric Foreign Relationships in Asia. Singapore: World Scientific Press, $2010 b$.

Woodside, Alexander. Vietnam and the Chinese Model: A Comparison of Vietnamese and Chinese Government in the First Half of the Nineteenth Century. Cambridge: Harvard University Press, 1971.

Zhang Juan. "Border Opened up: Everyday Business in a China-Vietnam Frontier”. Doctoral dissertation, Macquarie University, 2011.

—. "A Trafficking 'Non-Spot' in a China-Vietnam Border Town". In Labour Migration and Human Trafficking in Southeast Asia: Critical perspectives, edited by Michele Ford, Lenore Lyons, and Willem van Schendel. Oxford: Routledge, 2012.

Zhang Jun, and Peidong Sun. "When Are You Going to Get Married? Parental Matchmaking and Middle-Class Women in Contemporary Urban China". 
In Wives, Husbands, and Lovers: Marriage and Sexuality in Hong Kong, Taiwan, and Urban China, edited by Deborah S. Davis and Sara L. Friedman. Stanford: Stanford University Press, 2014.

Zhang Xiaoming. "China's 1979 War with Vietnam: A Reassessment". China Quarterly 184 (2005): 851-74.

Zhou Lei, and Duong Bich Hanh. "Sex Work in the Sino-Vietnamese Borderlands". Asian Anthropology 10, no. 1 (2011): 81-100. 